\title{
KESALAHAN PENGGUNAAN KONJUNGSI \\ DALAM TEKS EKSPLANASI \\ SISWA KELAS XI SMA PGRI 2 PADANG \\ PROPOSAL
}

untuk memenuhi tugas mata kuliah metode penelitian yang dibina oleh Prof. Dr. Syahrul R, M.Pd.

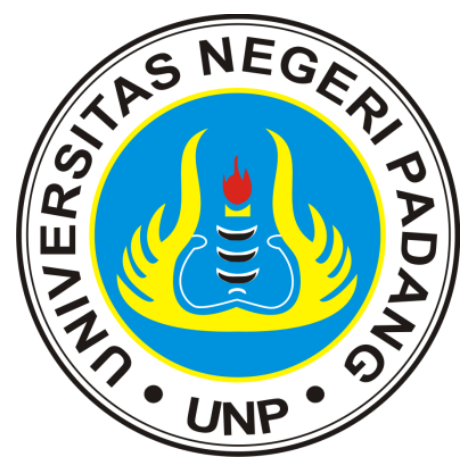

AYU PERMATA SARI

NIM 19016079/2019

PROGRAM STUDI PENDIDIKAN BAHASA INDONESIA JURUSAN BAHASA DAN SASTA INDONESIA DAN DAERAH FAKULTAS BAHASA DAN SENI UNIVERSITAS NEGERI PADANG 


\section{BAB I \\ PENDAHULUAN}

\section{A. Latar Belakang Masalah}

Menulis merupakan salah satu keterampilan berbahasa yang harus dikuasai

oleh siswa (Suprihatin et al., 2017). Menurut Paul (Setiawan et al., 2019) menyatakan bahwa menulis merupakan tingkatan tertinggi dari keterampilan berbahasa yang lainnya yaitu keterampilan membaca, menyimak dan berbicara. Menurut Saddono (Suprihatin et al., 2017) meskipun dalam proses pemerolehan berbahasa keempat keterampilan tersebut tidak diperoleh dalam waktu bersamaan, tetapi keempat keterampilan tersebut saling terkait satu sama lain. Menulis juga merupakan suatu proses atau aktivitas yang produktif karena dapat menghasilkan produk berupa karya tulis yang dapat dijadikan sebagai alat penyampaian pesan atau komunikasi (Tarigan, 2013). Menulis adalah kegiatan menyampaikan sesuatu menggunakan bahasa melalui tulisan, dengan maksud dan pertimbangan tertentu untuk mencapai sesuatu yang dikendaki (Suprihatin et al., 2017).

Kalimat yang tidak koheren atau salah tanda baca sering kali terjadi dari konjungsi yang disalahgunakan (Kusumawardhani, 2017). Chaer (Novita et al., 2018) menyatakan bahwa konjungsi adalah kata-kata yang digunakan untuk menghubungkan kata dengan kata, klausa dengan klausa, atau kalimat dengan kalimat. Konjungsi adalah kata tugas yang menghubungkan dua satu bahasa yang sederajat (Alwi, 2003). Sejalan dengan itu Sudaryat menyatakan konjungsi merupakan kata-kata yang digunakan untuk menghubungkan unsur-unsur sintakis dalam satuan yang lebih besar (Sudaryat, 2008). Kridalaksana berpendapat bahwa konjungsi terdiri atas sebab-akibat, pertentangan, kelebihan, perkecualian, konsesif, tujuan, penambahan, pilihan, harapan, urutan, perlawanan, waktu, syarat, dan cara (Nurfitriani et al., 2014). 
Abidin (Abidin, 2012) menyatakan rendahnya kemampuan menulis peserta didik disebabkan oleh berbagai faktor. Salah satu faktor yang dominan adalah rendahnya peran pendidik dalam membina peserta didik dalam menulis. Selain itu pembelajaran yang masih menggunakan metodologi mengajar tradisional. Cara mengajar masih bersifat otoriter dan berpusat pada pendidik. Pendidik memberi ceramah kepada peserta didik sementara peserta didik hanya mendengarkan. Hal ini senada dengan pendapat Ruganda bahwa pembelajaran menulis sekarang ini masih dilakukan dengan pola-pola tradisional, pendidik menerangkan teori tentang menulis lalu menugasi peserta didik untuk menulis atau mengarang sesuai dengan teori (Ruganda, 2009).

Keterampilan menulis merupakan salah satu keterampilan berbahasa dalam kurikulum 2013. Berdasarkan keempat keterampilan berbahasa, keterampilan menulis sering kali menjadi sorotan, karena kurangnya motivasi dan penguasaan siswa dalam menulis (Andyani et al., 2016). Keterampilan menulis dikembangkan melalui berbagai teks. Salah satu jenis teks dalam kurikulum 2013 untuk mengembangkan keterampilan menulis siswa SMA adalah teks eksplanasi. Keterampilan menulis teks eksplanasi tertuang dalam KD 4.4 yakni memproduksi teks eksplanasi secara lisan atau tulisan dengan memperhatikan struktur dan kebahasaan. Berdasarkan KD tersebut, siswa diharapkan mampu menerapkan struktur dan kebahasaan yang tepat dalam menulis teks eksplanasi.

Penelitian yang telah dilakukan di Indonesia menunjukkan bahwa siswa masih mengalami kesulitan dalam menulis teks eksplanasi. Kendala tersebut meliputi siswa masih sulit menguasai konsep teks eksplanasi (Budi, 2017), rendahnya motivasi siswa dalam belajar (Sudirman, 2009), kesulitan siswa dalam menuangkan gagasan melalui bahasa tulis, kesulitan siswa memulai proses menulis, kesulitan siswa menentukan kata yang tepat (Nurjanah et al., 2020), dan kesulitan siswa menjelaskan struktur teks eksplanasi (Ekawati et al., 2019). 
Beberapa peneliti telah menyelidiki faktor lainnya yang menyebabkan keterampilan menulis sulit dikuasai, misalnya penelitian di Inggris menunjukkan bahwa faktor yang mempengaruhi ketrampilan menulis yaitu kurangnya umpan balik untuk memperbaiki kesalahan tata bahasa yang dibuat siswa (Sermsook et al., 2017).

B. Identifikasi Masalah

Berdasarkan uraian yang telah dikemukakan dalam latar belakang masalah

di atas, maka identifikasi masalah dalam penelitian ini adalah sebagai berikut. Pertama, kurangnya pemahaman siswa mengenai penggunaan konjungsi yang sesuai dengan kaidah bahasa Indonesia. Kedua, Masih banyak kesalahan penggunaan konjungsi dalam teks eksplanasi siswa. Ketiga, teks eksplanasi yang ditulis siswa sering menggunakan konjungsi yang tidak tepat. Keempat, konjungsi yang sering digunakan siswa dalam menulis teks eksplanasi. Kelima, bentuk kesalahan penggunaan konjungsi yang sering dilakukan siswa.

\section{Batasan Masalah}

Berdasarkan identifikasi masalah tersebut, permasalahan penelitian ini

dibatasi pada kesalahan penggunaan konjungsi dalam teks eksplanasi siswa kelas XI SMA PGRI 2 Padang.

\section{Rumusan Masalah}

Rumusan masalah dalam penelitian ini adalah sebagai berikut. Pertama,

Bagaimana kemampuan siswa dalam menggunakan konjungsi pada saat menulis teks eksplanasi ? Kedua, kesalahan penggunaan konjungsi apa sajakah yang terdapat pada karangan teks eksplanasi siswa kelas XI SMA PGRI 2 Padang? 


\section{E. Tujuan Penelitian}

Berdasarkan rumusan masalah di atas, tujuan penelitian ini adalah sebagai

berikut. Pertama, mengetahui pemahaman siswa siswa kelas XI SMA PGRI 2 Padang terhadap penggunaan konjungsi dalam menulis teks eksplanasi. Kedua, mengetahui kesalahan penggunaan konjungsi dalam teks eksplanasi karya siswa kelas XI SMA PGRI 2 Padang.

\section{F. Manfaat Penelitian}

Penelitian ini memiliki dua manfaat, yaitu manfaat teoritis dan manfaat

praktis. Secara teoritis, penelitian ini diharapkan bermanfaat untuk menambah dan memperkaya teori ilmu pengetahuan dalam bidang menulis teks eksplanasi. Secara praktis, hasil penelitian ini diharapkan dapat memberikan manfaat kepada pihak-pihak berikut. Pertama, bagi guru, khususnya guru bahasa Indonesia di SMA PGRI 2 Padang, yaitu sebagai bahan masukan dalam meningkatkan hasil belajar teks eksplanasi.

\section{G. Definisi Operasional}

Untuk menghindari terjadinya kesalahan penafsiran dalam penelitian,maka

diberikan definisi operasional sebagai berikut.

1. Kesalahan Penggunaan Konjungsi

Penggunaan konjungsi yang tidak benar dapat menyebabkan kalimat

menjadi tidak efektif dan mengubah maksud kalimat. Kesalahan penguasaan penggunaan konjungsi yang akan dibahas dalam penelitian ini yaitu bentuk kesalahan penggunaan konjungsi dalam menulis teks eksplanasi siswa kelas XI SMA PGRI 2 Padang.

2. Menulis Teks Eksplanasi

Menulis teks eksplanasi yang dimaksud adalah keterampilan 
menuliskan atau memproduksi teks eksplanasi yang termuat dalam kurikulum 2013. Indikator yang digunakan sebagai alat ukur keterampilan menulis teks eksplanasi siswa kelas XI SMA PGRI 2 Padang adalah (1) kelengkapan struktur teks eksplanasi, (2) ketepatan penggunaan konjungsi dalam teks eksplanasi. 


\section{BAB II}

\section{KAJIAN PUSTAKA}

\section{A.Kajian Teori}

Berdasarkan permasalahan peneliti, terdapat dua kategori yang akan diuraikan pada kajian teori ini. Pertama, keterampilan menulis teks eksplanasi. Kedua, kesalahan penggunaan konjungsi dalam teks eksplanasi karya siswa kelas XI SMA PGRI 2 Padang.

\section{Keterampilan Menulis Teks Eksplanasi}

Teori yang akan diuraikan dalam keterampilan menulis teks eksplanasi, yaitu (a) pengertian menulis, (b) pengertian teks eksplanasi, (c) struktur teks eksplanasi, (d) kaidah kebahasaan teks eksplanasi, dan (e) langkahlangkah menulis teks eksplanasi.

\section{a.Pengertian Menulis}

Upaya melahirkan perasaan dan pikiran lewat bahasa tulis disebut menulis (Hernowo, 2002). Menulis sebagai sebuah keterampilan berbahasa adalah kemampuan seseorang dalam mengemukakan gagasan, perasaan, dan pemikiran-pemikirannya kepada orang atau pihak dengan menggunakan media tulisan (Nurjamal et al., 2011). Sementara itu, Suparno (Suparno \& Yunus, 2008) mengemukakan bahwa menulis dapat didefinisikan sebagai suatu kegiatan menyampaikan pesan dengan menggunakan bahasa tulis sebagai alat medianya.

Berdasarkan definisi tersebut, dapat disimpukan bahwa menulis merupakan sebuah kemampuan menuangkan ide dalam bentuk tulisan melalui kalimat-kalimat yang disusun secara utuh, lengkap, dan jelas sehingga ide tersebut dapat dikomunikasikan kepada pembaca.

\section{b.Pengertian Teks Eksplanasi}

Keterampilan berbahasa dipandang sebagai salah satu 
keterampilan penggunaan bahasa untuk mengkomunikasikan pesan, selain keterampilan membaca, menyimak dan berbicara (Indihadi, 2018). Keterampilan menulis ditandai dengan penggunaan bahasa tulis bersifat produktif. Seseorang dituntut unuk mengkomunikasikan pesan kepada pembaca melalui tulisan sesuai tema, maksud, tujuan serta konteks.

Teks eksplanasi adalah teks yang menjelaskan suatu peristiwa alam, peristiwa sosial dan budaya (E Kosasih \& Endang, 2014). Priyatni (Priyatni, 2014) juga berpendapat bahwa teks eksplanasi merupakan teks yang berisikan penjelasan tentang proses yang berhubungan dengan fenomena alam, sosial, pengetahuan, budaya dan lain.

Berdasarkan definisi diatas, dapat disimpulkan bahwa teks eksplanasi adalah teks yang berisi penjelasan lengkap mengenai topik yang berhubungan dengan fenomena tertentu, fenomena tersebut dapat berhubungan dengan alam dan sosial yang terjadi dalam kehidupan sehari -hari.

\section{c.Struktur Teks Eksplanasi}

Pada umumnya, struktur teks eksplanasi terdiri atas tiga bagian yaitu (1) pernyataan umum, (2) penjelasan, dan (3) kesimpulan. Masingmasing akan dijelasakan sebagai berikut.

Kosasih menyatakan bahwa teks eksplanasi disusun dengan struktur pertama yaitu pernyataan umum. Pernyataan umum berisi fenomena, baik fenomena alam maupun fenomena sosial yang akan dibahas. Bagian kedua dari strukur teks eksplanasi adalah penjelasan. Penjelasan berisi argumen lebih lanjut mengenai fenomena tersebut. Penjelasan yang dimaksud disini bisa berupa urutan mengapa fenomena tersebut dapat terjadi. Bagian ketiga dari struktur teks eksplanasi yaitu kesimpulan. Kesimpulan berisi ringkasan dari poin-poin yang sudah dijelaskan sebelumnya (Engkos Kosasih, 2013).

Isnatun dan Farida (Isnatun \& Farida, 2013) menyatakan bahwa 
teks eksplanasi disusun dengan struktur yang terdiri atas bagian pernyataan umum, deretan penjelas, dan penutup. Bagian pernyataan umum berisi informasi singkat tentang suatu topik yang dibicarakan. Bagian penjelasan berisi tentang penjelasan detail mengenai proses atau peristiwa yang terjadi. Penutup berisi kesimpulan atau pendapat penulis tentang peristiwa yang terjadi. Bagian ini boleh ada atau tidak ada.

Berdasarkan penjelasan di atas, dapat disimpukan bahwa struktur teks eksplanasi ada tiga yaitu pernyataan umum, penjelasan, dan penutup. d.Kaidah Kebahasaan Teks Eksplanasi

Setiap teks memiliki ciri-ciri tertentu. Ciri yang dimiliki suatu teks dapat digunakan sebagai pembeda antara sebuah teks dengan teks lainnya. Kaidah kebahasaan teks eksplanasi adalah sebagai berikut.

\section{a.Menggunakan Konjungsi Waktu}

Konjungsi merupakan kata hubung. Konjungsi banyak jenisnya, salah satunya konjungsi waktu. Konjungsi waktu diantaranya adalah sementara itu, setelah itu, kemudian, lalu, setelah, sesudah, sebelum, seketika, tatkala, saat, dan sebelum itu. Konjungsi waktu fungsinya adalah untuk menyatakan waktu. Konjungsi waktu digunakan dalam teks eksplanasi karena teks eksplanasi berisi proses terjadinya sesuatu. Proses terjadinya sesuatu umumnya dijelasakan denha urutan waktu. Oleh karena itu konjungsi waktu digunakan dalam teks eksplanasi.

\section{b.Menggunakan Konjungsi Sebab Akibat}

Konjungsi sebab akibat di antaranya adalah sebab, karena, akibatnya, oleh karena itu, dan sehingga. Konjungsi sebab akibat menghubungkan satuan kebahasaan untuk menyatakan hubungan sebab akibat suatu proses fenomena alam yang dijelaskan dengan mengurutkan kejadian-kejadian. Oleh karena itu, konjungsi sebab akibat digunakan untuk menulis teks eksplanasi (Isnatun \& Farida, 2013). 
Knapp dan Watkins mengatakan, eksplanasi umumnya memerlukan kata sambung yang bergabung dengan kata kerja sehingga secara logis menunjukkan urutan yang sementara ketika, maka, pertama, setelah ini, sebab akibat, misalnya, karena, begitu. Berdasarkan pendapat ahli di atas, maka dapat disimpulkan bahwa ciri kebahasaan teks eksplanasi adalah menggunakan kata hubung berupa konjungsi waktu dan konjungsi sebab akibat.

e.Langkah-Langkah Menulis Teks Eksplanasi

Dalam menulis teks eksplanasi ada beberapa hal yang harus diperhatikan, yaitu menentukan tema tulisan, mengumpulkan bahan tulisan, membuat kerangka tulisan, dan mengembangkan tulisan.

\section{Kesalahan Penggunaan Konjungsi}

a.Pengertian Konjungsi

Penyebutan kata atau istilah yang berfungsi sebagai penanda hubungan bermacam-macam. Alwi (Hasan, 2003) menyebut konjungsi dengan istilah konjungtor, sedangkan Ramlan (Ramlan, 2008) dan Chaer menyebutnya dengan istilah kata penghubung.

Alwi,dkk (Hasan, 2003) berpendapat bahwa konjungtor adalah kata tugas yang menghubungkan dua satuan bahasa yang sederajat. Selain itu Chaer (Chaer, 2008) berpendapat bahwa konjungsi adalah kata-kata yang menghubungkan kata dengan kata, kalusa dengan klausa, atau antara kalimat dengan kalimat, bisa juga antara paragraf dengan paragraf. Menurut pendapat Ramlan (Ramlan, 2008) konjungsi adalah kata yang berfungsi menghubungkan kata/frasa/klausa lain. Kunjana Rahardi (Rahardi, 2009) mengemukakan bahwa kelas kata konjungsi atau konjungtor menghubungkan satuan kata dengan satuan kata, satuan frasa dengan satuan frasa, dan satuan klausa dengan satuan klausa.

Berdasarkan beberapa pendapat para ahli di atas, maka dapat disimpulkan bahwa konjungsi adalah kata penghubung yang menghubungkan satuan bahasa yang sederajat (kata dengan kata, frasa dengan frasa, dan klausa dengan klausa). 


\section{b.Jenis-Jenis Konjungsi}

Ada beberapa jenis konjungsi yang akan diungkapkan oleh para ahli bahasa. Menurut Chaer (Chaer, 2008) membagi konjungsi ke dalam dua klasifikasi yaitu (1) konjungsi koordinatif, dan (2) konjungsi subordinatif. 1.Konjungsi Koordinatif

Menurut Chaer (Chaer, 2015), konjungsi koordinatif adalah konjungsi yang menghubungkan dua buah konstituen yang kedudukannya sederajat. Konjungsi ini dibedakan pula atas konjungsi yang menghubungkan menyatakan. Berikut ini adalah pengelompokkan konjungsi koordinatif menurut Abdul Chaer.

\section{a)Konjungsi Penjumlahan}

Chaer (Chaer, 2015) menyatakan konjungsi penjumlahan adalah konjungsi yang menghubungkan menjumlahkan. Yang termasuk konjungsi ini adalah konjungsi dan, serta, dan dengan.

b)Konjungsi Pemilihan

Menuurut Chaer (Chaer, 2015) konjungsi pemilihan adalah konjungsi yang menghubungkan memilih salah satu konstituen yang dihubungkan. Yang termasuk konjungsi ini hanyalah kata atau.

c)Konjungsi Pertentangan

Menurut (Chaer, 2015)Chaer konjungsi pertentangan adalah konjungsi yan menghubungkan pertentangan. Yang termasuk konjungsi ini adalah kata tetapi, namun, sedangkan, dan sebaliknya.

d)Konjungsi Pembetulan

Chaer menyatakan konjungsi pembetulan adalah konjungsi yang menghubungkan dan membetulkan atau meralat kedua konstituen yang dihubungkan. Yang termasuk konjungsi ini adalah kata melainkan, dan hanya.

e)Konjungsi Penegasan

Konjungsi penegasan atau penguatan adalah konjungsinyang menghubungkan, menegaskan, dan menguatkan. Yang termasuk 
konjungsi ini adalah kata-kata bahkan, apalagi, lagipula, hanya, itupun, begitu juga, dan demikian pula.

f)Konjungsi Pembatas

Menurut Chaer (Chaer, 2015) konjungsi pembatas adalah konjungsi yang menghubungkan membatasi. Yang termasuk konjungsi ini adalah kata kecuali dan hanya.

g)Konjungsi Pengurutan

Menurut Chaer, konjungsi pengurutan adalah konjungsi yang digunakan klausa dengan klausa dalam urutan beberapa kejadian atau peristiwa secara kronologis. Yang termasuk konjungsi ini adalah kata sesudah, sebelum, lalu, mula-mula, ketiga, dan seterusnya.

\section{Konjungsi Subordinatif}

Chaer (Chaer, 2015) mengungkapkan bahwa konjungsi subordinatif adalah konjungsi yang menghubungkan dua buah konstituen yang kedudukannya tidak sederajat.

a)Konjungsi Penyebaban

Chaer (Chaer, 2015) mengatakan konjungsi penyebab adalah konjungsi yang menghubungkan menyatakan sebab terjadinya keadaan atau peristiwa pada klausa utama. Yang termasuk konjungsi penyebab adalah karena, sebab, dan lantaran.

b)Konjungsi Persyaratan

Chaer mengatakan bahwa konjungsi persyaratan bahwa konjungsi yang menghubungkan menyatakan syarat untuk keadaan atau peristiwa yang terjadi pada klausa utama dalam sebuah kalimat majemuk subordinatif. Yang termasuk persyaratan adalah kata jika, jkalau, bila, apabila, dan asal.

c)Konjungsi Tujuan

Menurut Chaer (Chaer, 2015) konjungsi tujuan adalah konjungsi yang menghubungkan tujuan yang dilakukan tindakan pada klausa pertama. Yang termasuk konjungsi ini adalah kata agar, supaya, guna, dan untuk. 
B.Penelitian yang Relevan

Penelitian yang relevan dengan penelitian ini di antaranya adalah sebagai berikut.

Pertama, Penelitian Supiyanto (2015) mengkaji tentang Jenis Kesalahan Berbahasa dalam Penggunaan Konjungsi dalam Kalimat Majemuk pada Tugas Akhir Mahasiswa Program Studi Teknik Elektro Universitas Sanata Dharma lulusan tahun 2013. Hasil dari penelitian ini adalah kesalahan penggunaan konjungsi dalam kalimat majemuk yang dibuat oleh mahasiswa Program Studi Teknik Elektro tahun 2013 meliputi: (1) kesalahan penggunaan konjungsi dalam kalimat majemuk setara, (2) kesalahan penggunaan konjungsi dalam kalimat majemuk bertingkat, dan (3) kesalahan penggunaan konjungsi dalam kalimat majemuk campuran. Kesalahan penggunaan konjungsi dalam kalimat majemuk setara yangpaling banyak mengalami kesalahan adalah dalam kalimat majemuk setara yang menyatakan penjumlahan, kesalahan dalam kalimat majemuk bertingkat yang paling banyak mengalami kesalahan adalah dalam kalimat majemuk bertingkat klausa anak keterangan syarat, dan kesalahan penggunaan konjungsi dalam kalimat majemuk campuran yang paling banyak mengalami kesalahan adalah konjungsi "dan".

Kedua, penelitian Yanuarti (2012) yang berjudul Analisis Penggunaan Preposisi dan Konjungsi pada Karangan Siswa Kelas X SMA Negeri Mojotengah Wonosobo Tahun Ajaran 2011/2012. Hasil dari penelitian ini meliputi: (1) kesalahan preposisi di dan ke yang sering salah dalam penulisan afiks di- dan ke-, (2) kesalahan memilih preposisi dalam membentuk kalimat dan kesalahan penggunaan konjungsi, yaitu pengunaan konjungsi yang berlebihan dan penggunaan konjungsi di awal kalimat yang tidak tepat, sedangkan terjadinya kesalahan kalimat adalah ketidaktelitian siswa tentang kaidah penulisan kata, kaidah pemakaian tanda baca dan faktor kosa kata siswa yang belum cukup bayak.

Penelitian ini memiliki persamaan dan perbedaan dengan penelitian sebelumnya. Persamaan penelitian ini dengan penelitian sebelumnya 
adalah sama-sama meneliti tentang kesalahan penggunaan konjungsi. Sementara itu, perbedaannya terletak pada populasi dan variabel terikatnya. Dalam penelitian ini, populasi penelitiannya adalah siswa kelas XI SMA PGRI 2 Padang. Variabel terikat dalam penelitian ini ialah teks eksplanasi karya siswa kelas XI SMA PGRI 2 Padang.

\section{C.Kerangka Konseptual}

Secara konseptual terdapat kaitan antara variabel kesalahan penggunaan konjungsi dengan teks eksplanasi. Kesalahan penggunaan konjungsi adalah variabel bebas $(X)$ sedangkan teks eksplanasi siswa kelas XI SMA PGRI 2 Padang adalah variable terikat (Y). Untuk lebih jelasnya digambarkan dalam kerangka konseptual berikut.

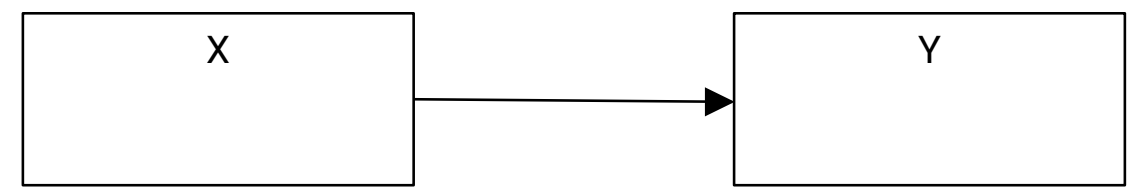

Gambar 1

Kerangka Konseptual

Keterangan :

$X=$ Kesalahan Penggunaan Konjungsi

$\mathrm{Y}=$ Teks Eksplanasi Siswa Kelas XI SMA PGRI 2 Padang 


\section{BAB III \\ METODOLOGI PENELITIAN}

\section{A.Jenis Penelitian}

Penelitian yang berjudul Kesalahan Penggunaan Konjungsi dalam Teks Eksplanasi Siswa Kelas XI SMA PGRI Padang ini merupakan penelitian deskriptif.

Penelitian deskriptif adalah penelitian yang diarahkan untuk memberikan

gejala-gejala, fakta-fakta, atau kejadian-kejadian secara sistematis dan akurat,

mengenai sifat-sifat populasi atau daerah tertentu. Dalam penelitian deskriptif

cenderung tidak mencari atau menerangkan saling hubungan dan menguji hipotesis (Nurul Zuriah 2006:47). Menurut (J.W. Creswell, 2004) dalam Etta

Mamang Sangadji \& Sophia (2010:24), penelitian deskriptif adalah metode penelitian yang berusaha menggambarkan atau menginterpretasikan objek apa

adanya. Jadi, dari kedua pengertian di atas dapat disimulkan bahwa penelitian

dekriptif adalah penelitian yang dilakukan untuk menggambarkan gejala, fakta,

dan kejadian apa adanya secara akurat dan sistematis.

Melalui penelitian ini, penulis hendak memberikan gambaran tentang kesalahan berbahasa yang ditemukan dalam karangan narasi yang dibuat oleh

siswa kelas XI SMA PGRI 2 Padang. Melalui metode deskriptif, penulis menganalisis keseluruhan data yang ditinjau dari penggunaan konjungsi dalam dokumen yang diteliti, kemudian mendeskripsikan hal-hal yang sudah ditemukan sesuai dengan permasalahan yang telah dirumuskan.

B.Populasi dan Sampel

Populasi dalam penelitian ini adalah siswa kelas XI SMA PGRI 2 
Padang. Jumlah siswa kelas XI adalah sebanyak 120 orang yang tersebar dalam empat kelas. Sampel merupakan bagian dari populais yang akan diteliti. Dikarenakan populasi penelitian lebih dari seratus siswa, maka perlu digunakan teknik pengambilan sampel. Pemilihan sampel penelitian ini dilakukan dengan teknik simple random sampling (teknik proposioal secara acak) dengan tujuan agar semua populasi dapat terwakili.

Subjek dalam penelitian ini berjumlah lebih dari 100. Hal ini mengisyaratkan bahwa jumlah subjek diambil antara $10-15 \%$ atau $20-25 \%$ atau lebih (Arikunto, 2010). Dalam penelitian ini, peneliti mengambil sampel sebanyak $20 \%$ dari jumlah populasi perkelas. Populasi dan sampel tersebut dapat dilihat pada tabel 3 berikut ini.

\begin{tabular}{|l|l|l|l|}
\hline No & Kelas & Populasi & Sampel \\
\hline 1 & 2 & 3 & 4 \\
\hline 1 & IX IPA & 30 orang & 6 orang \\
\hline 2 & IX IPS 1 & 30 orang & 6 orang \\
\hline 3 & IX IPS 2 & 30 orang & 6 orang \\
\hline 4 & IX IPS 3 & 30 orang & 6 orang \\
\hline
\end{tabular}

\section{Data dan Sumber Data}

Data dalam penelitian ini adalah kalimat-kalimat yang mengalami kesalahan penggunaan konjungsi dalam teks eksplanasi karya siswa kelas XI SMA PGRI 2 Padang. Teks tersebut berjumlah 24 teks yang diperoleh dari siswa kelas XI SMA PGRI 2 Padang. Sumber data dalam penelitian ini adalah teks eksplanasi siswa kelas XI SMA PGRI 2 Padang.

D.Instrumen Penelitian

Instrumen penelitian yang digunakan dalam memperoleh data adalah peneliti sendiri. Peneliti memiliki peranan yang besar dalam memegang kendali dan menentukan data yang diperoleh. Oleh sebab itu 
instrumen yang digunakan dalam penelitian ini adalah peneliti sendiri.

\section{E.Teknik Pengumpulan Data}

Pengumpulan data adalah proses yang dilakukan peneliti untuk mengumpulkan informasi yang dibutuhkan. Cara yang dilakukan peneliti untuk mengumpulkan data adalah melakukan tes mengarang. Melalui tes ini, siswa diminta mengarang sebuah teks eksplanasi dengan tema yang ditentukan sendiri.

\section{F.Teknik Analisis Data}

Penelitian dilaksanakan di SMA PGRI 2 Padang. Teknik yang dilakukan dalam pengumpulan data adalah memberikan tugas berupa siswa diminta menulis teks eksplanasi karya sendiri.

Adapun analisis data dalam penelitian ini menggunaan metode deskriptif. Adapun langkah-langkah yang dilakukan peneliti dalam menganalisis data antara lain :

1.Peneliti mengumpulkan data dengan cara membaca dan mencermati isi dari teks eksplanasi siswa kelas XI SMA PGRI 2 Padang.

2.Peneliti mengidentifikasi kesalahan berbahasa khususnya kesalahan yang ditinjau dari penggunaan konjungsi.

3.Peneliti mengidentifikasi penggunaan konjungsi dalam teks eksplanasi berdasarkan jenis-jenis kesalahannya.

4.Peneliti memberikan kode pada setiap teks eksplanasi siswa kelas XI SMA PGRI 2 Padang.

5.Peneliti mencatat dan mengelompokkan kesalahan meurut jenisnya ke dalam tabel data kemudian membuat pembenarannya. 


\section{Daftar Pustaka}

Abidin, Y. (2012). Pembelajaran Bahasa Berbasis Pendidikan Karakter. Bandung : Refika Aditama.

Alwi, H. (2003). Tata Bahasa Baku Bahasa Indonesia. Jakarta : Balai Pustaka.

Andyani, N., Sddhono, K., \& Mujyanto, Y. (2016). Peningkatan Kemampuan Menulis Teks Eksplanasi dengan Menggunakan Media Audiovisual Pada Siswa Sekolah Menengah Pertama. Jurnal Penelitian Bahasa, Sastra Indonesia Dan Pengajarannya, 4(2), 16.

Arikunto, S. (2010). Prosedur Penelitian : Suatu Pendekatan Praktik. Jakarta : Rineka Cipta.

Budi, E. N. (2017). Penerapan Pembelajaran Virtual Class Pada Materi Teks Eksplanasi untuk Meningkatkan Aktivitas dan Hasil Belajar Bahasa Indonesia Siswa Kelas XI IPS 2 SMA 1 KUDUS Tahun 2017. Jurnal Pendidikan IImu Sosial, 27(2), 63-64.

Chaer, A. (2008). Sintaksis Bahasa Indonesia (Pendekatan Proses). Jakarta : Rineka Cipta.

Chaer, A. (2015). Morfologi Bahasa Indonesia: Pendekatan Proses. Jakarta : Rineka Cipta.

Ekawati, L., Bella, R. S., \& Firmansyah, D. (2019). Meningkatkan Kemampuan Menulis Teks Eksplanasi dengan Menggunakan Metode Picture and picture Siswa Kelas XI Teknik Kendaraan Ringan (TKR). Jurnal Pendidikan Bahasa Dan Sastra Indonesia, 2(3), 328.

Hasan, A. (2003). Tata Bahasa Baku Bahasa Indonesia. Jakarta : Balai Pustaka.

Hernowo. (2002). Mengikat Makna. Bandung : Kaifa.

Indihadi, D. (2018). Teknik Brain Strorming dalam Pembelajaran Menulis di Sekolah Dasar. Jurnal Siliwangi : Seri Pendidikan, 4(1), 17-22.

Isnatun, S., \& Farida, U. (2013). Mahir Berbahasa Indonesia. Bogor : Yudhistira.

Kosasih, E, \& Endang, K. (2014). Jenis-Jenis Teks. Bandung : Bandung : 
Yrama Widya.

Kosasih, Engkos. (2013). Mandiri Mengasah Kemampuan Diri Bahasa Indonesia untuk SMP/MTS Kelas VII. Jakarta : Erlangga.

Kusumawardhani, P. (2017). The Analysis Of Conjunctions In Writing An English Narrative Composition: A Syntax Perspective. Wanastra, 9(1), 3.

Novita, B., Pauji, E. L., Meliyarianti, F., \& Sudrajat, R. T. (2018). Analisis Penggunaan Konjungsi dan Tanda Baca dalam Teks LHO Pada Siswa SMA kelas x. Junal Pendidikan Bahasa Dan Sastra, 1(2), 128.

Nurfitriani, Bahry, R., \& Azwardi. (2014). Analisis Kohesi dan Koherensi dalam Proposal Mahasiswa PBSI Tanggal 23 Desember 2014. Jurnal Bahasa Dan Sastra, 12(1), 39-48.

Nurjamal, Daeng, Sumirat, W., \& Darwis, R. (2011). Terampilan Berbahasa

Menyusun Karya Tulis Akademik, Memandu Acara (MC-Moderator), dan Menulis Surat. Bandung : Alfabeta.

Nurjanah, R. S., Wikanengsih, \& Rostikawati, Y. (2020). Pembelajaran Menulis Teks Eksplanasi Menggunakan Metode Mind Mapping. Junal Pendidikan Bahasa Dan Sastra Indonesia, 3(4), 599.

Priyatni, E. T. (2014). Desain Pembelajaran Bahasa Indonesia dan Kurikulum 2013. Jakarta : Bumi Aksara.

Rahardi, K. (2009). Penyuntingan Bahasa Indonesia untuk Karang Mengarang. Jakarta : Erlangga.

Ramlan. (2008). Kalimat, Konjungsi, dan Preposisi Bahasa Indonesia dalam Penulisan Karangan IImiah. Yogyakarta : USD.

Ruganda. (2009). Peningkatan Hasil Pembelajaran Menulsi Deskripsi Melalui Model Delikan di Kelas V SD Kalikoa, Kecamatan Kadaung. Metalingua: Jurnal Penelitian Bahasa, 10(1).

Sangadji Mangang Etta dan Sophia. (2010). Metodologi Penelitian : Pendekatan Praktis dalam Penelitian. Yogyakarta : Andi.

Sermsook, K., Liamnimitr, J., \& Pochakorn, R. (2017). The Impact of Theacher Corrective Feedback on ELF Student Writers' Grammatical Improvement. English Language Teaching, 10(10). 
Setiawan, D., Sopandi, W., \& Hartati, T. (2019). Kemampuan Menulis Teks Eksplanasi dan Penguasaan Konsep Siswa Sekolah Dasar Melalui Implementasi Model Pembelajaran RADEC. Jurnal Pendidikan Dasar Dan Pembelajaran, 9(September), 130.

Sudaryat, Y. (2008). Makna dalam Wacana. Bandung : CV Yrama Widya.

Sudirman. (2009). Interaksi \& Motivasi Belajar Mengajar. Jakarta : Grafindo Persada.

Suparno, \& Yunus, M. (2008). Keterampilan Dasar Menulis. Jakarta : Universitas Terbuka.

Suprihatin, Setiawan, B., \& Anindyarini, A. (2017). Kemampuan Menulis Teks Pidato. Jurnal Penelitian Bahasa, Sastra Indonesia Dan Pengajarannya, 5(2), 146.

Tarigan, H. G. (2013). Menulis Sebagai Suatu Keterampilan Berbahasa. Bandung: Angkasa. 